\title{
The Volcanic Earthquake Swarm of October 20, 2009 in the Tatun Area of Northern Taiwan
}

\author{
Hsin-Chieh $\mathrm{Pu}^{1}$, Cheng-Horng Lin ${ }^{2, *}$, Yu-Chih Huang ${ }^{2}$, Li-Chin Chang ${ }^{2}$, Hsiao-Fen Lee ${ }^{2}$, Peih-Lin Leu ${ }^{1}$, \\ Nai-Chi Hsiao ${ }^{1}$, Chien-Hsin Chang ${ }^{1}$, and Yih-Hsiung Yeh ${ }^{2}$ \\ ${ }^{1}$ Central Weather Bureau, Taipei, Taiwan \\ ${ }^{2}$ Institute of Earth Sciences, Academia Sinica, Taipei, Taiwan
}

Received 3 September 2013, revised 10 April 2014, accepted 11 April 2014

\begin{abstract}
On October 20,2009, a series of felt earthquakes with local magnitudes ranging from $2.8-3.2$ occurred in the Tatun volcanic area off the northern tip of Taiwan. Although there was no damage caused by those earthquakes, many residents in the Taipei metropolitan area, particularly for people who live near the Yangminshan National Park, felt strong ground shaking. In order to know what the possible mechanisms were that generated those earthquakes, we carefully examined seismic data recorded by a dense seismic array in the Tatun volcanic area. During the period between October 18 and 22, 2009 we detected at least 202 micro-earthquakes. Most of the earthquakes were relocated using the double-difference method and were clustered in the shallow crust beneath the Dayoukeng area, which is the strongest fumarole in the Tatun volcanic area. Among these earthquakes, 72 focal mechanisms were determined by polarizing the first $\mathrm{P}$-wave motion. Most earthquakes belonged to normal faulting. An extremely high $b$-value of 2.17 was obtained from those earthquakes. Based on the seismic variations in both the temporary and spatial distribution as well as an extremely high $b$-value, we conclude that the earthquake sequence on October 20, 2009 was a typically seismic swarm associated with possible active volcanism in the Tatun volcanic area.
\end{abstract}

Key words: Tatun volcano, Seismic swarm, High $b$-value, 1020 earthquake

Citation: Pu, H. C., C. H.Lin, Y.C.Huang, L.C.Chang, H.F. Lee, P. L. Leu, N.C. Hsiao, C. H. Chang, and Y. H. Yeh, 2014: The volcanic earthquake swarm of October 20, 2009 in the Tatun area of northern Taiwan. Terr. Atmos. Ocean. Sci., 25, 625-635, doi: 10.3319/TAO.2014.04.11.02(T)

\section{INTRODUCTION}

A series of unusual felt earthquakes occurred in the Tatun volcanic area of the northern tip of Taiwan on October 20, 2009. This was the first detection of a large number of micro-earthquakes by a dense seismic array in this area. This occurrence provided good opportunity to study the tectonic activity beneath the Tatun volcanic area. Although those earthquakes were not very large $\left(\mathrm{M}_{\mathrm{L}}=2.8\right.$ to 3.2) compared with significant seismicity in other parts of Taiwan where a convergent plate boundary is located (Lin 2002), most of the residents in the Taipei metropolitan area felt strong ground motion due to short epicenter distances as well as extremely shallow hypocenters. The residents in the Tatun volcanic area felt particularly strong shaking. In addition to 4 felt earthquakes, more than one hundred micro-earthquakes were detected by the Central Weather Bureau in the same area in the

\footnotetext{
* Corresponding author

E-mail:lin@earth.sinica.edu.tw
}

following 24 hours. Although there was no damage caused by those earthquakes, it is important to determine the possible casual mechanisms associated with those earthquakes, either volcanic activity or any active faults. The results will improve the understanding of generally geological characteristics in the Tatun volcanic area and provide valuable information to mitigate possible geological impact in the future.

Based on the general surface geology (Chen and Wu 1971; Ho 1988; Wang and Chen 1990; Lin et al. 2007), it is obvious that two possible mechanisms for generating those felt earthquakes might be directly considered in the Tatun volcanic area. The first is directly related to potential volcanism in the Tatun volcanic area. The second is related to an active fault, the Shanchiao fault (Fig. 1). Those felt earthquakes were located just in the Tatun volcanic area consisting of more than 20 volcanoes (Chen and Wu 1971; Wang and Chen 1990). Some recent studies suggest that the volcanoes in the Tatun volcanic area might be considered 
"dormant active volcanoes" (Song et al. 2000; Chen and Lin 2002; Yang et al. 2003; Konstantinou et al. 2007). The geochemical analyses from volcanic gas show the Helium isotope ratio of $\mathrm{He}^{3}$ and $\mathrm{He}^{4}$ ranges from 4.0 - 6.7 (Yang et al. 1999), strongly indicating that some mantle material might still be ascending into the shallow crust or surface. Secondly, numerous shallow micro-earthquakes as well as volcanic earthquakes have been detected by the dense seismic array in the Tatun volcanic area (Lin et al. 2005a, b; Konstantinou et al. 2007). Thirdly, some crust deformation has been repeatedly detected from a precise leveling survey at the particular area near the Dayoukeng fumarole in the past several years (Murase et al. 2014). Finally, the most recent volcanic ash dating result in the Tatun volcanic area shows the last eruption might be around 6000 years ago (Belousov et al. 2010). The felt earthquakes are therefore likely associated with active volcanism in the Tatun volcanic area.

There is also an active fault, the Shanchiao fault, crossing the Tatun volcanic area (Lin et al. 2007). This fault strikes along a NE-SW direction, from the town of Chinshan to the town of Kuando and then crosses the Tansui River to the Wuku and Shinchun areas (Fig. 1). This is a normal fault dipping southeastward about 62 degrees. It has been reactive roughly along the Chinshan fault, which is a non-active fault reported by the Central Geological Survey (Lin et al. 2007). The total length of this fault is about $60 \mathrm{~km}$. Based on drilling core samples (Huang et al. 2007), this fault has a $10-\mathrm{m}$ offset and experienced at least 3 ruptures over the last 14000 years. The last rupture was about $8400-8600$ years ago. The slip rate of the fault is about $1.8 \mathrm{~m}$ per one thousand years. Given the close distance between the Tatun volcanoes and Shanchiao fault, it has been difficult to find evidence to distinguish whether active volcanoes or the fault is driving seismic activity in this area.
In order to explore future volcanic activity it is necessary to study newly detected earthquakes and their physics. In this study we carefully examined the seismic data recorded by a dense seismic array in the Tatun volcanic area. In total, 4 felt earthquakes and 184 micro-earthquakes were relocated using the double-difference method (Waldhauser and Ellsworth 2000). The focal mechanisms of 72 earthquakes were determined from the first-motion polarizations of the $\mathrm{P}$-waves. To evaluate the seismic characteristics of this earthquake sequence, we also calculated the seismic $b$-value from the frequency-magnitude relationship. Finally, the possible driving mechanisms of those earthquakes are discussed according to the temporal and spatial distribution of those earthquakes and their focal mechanisms.

\section{BACKGROUND SEISMICITY}

Based on the earthquake catalog provided by the Central Weather Bureau, some clustered earthquakes have been reported in the shallow crust in the Tatun volcanic area since 1973 (Fig. 2a). Many of these earthquakes were scattered southeast of the Shanchiao fault. Most of them were unfelt because the seismic magnitudes were small $\left(\mathrm{M}_{\mathrm{L}}<3.0\right)$, except for some significant earthquake swarms (Fig. 2a). A seismic swarm is commonly defined as a group of earthquakes (1) that occur in a limited space and time, (2) have no mainshock of sufficient magnitude, and (3) do not follow well the general Omori's law characteristics. We selected those seismic swarms (Fig. 2a) based on the following criteria: (1) earthquakes were occurring within 1 day and spatial distances less than $5 \mathrm{~km}$ and (2) the magnitude differences were less than 1 . Those seismic swarms, non-aftershock activity, could be largely associated with magmatic intrusion (e.g., Hill 1977), or few aseismic deformation along faults
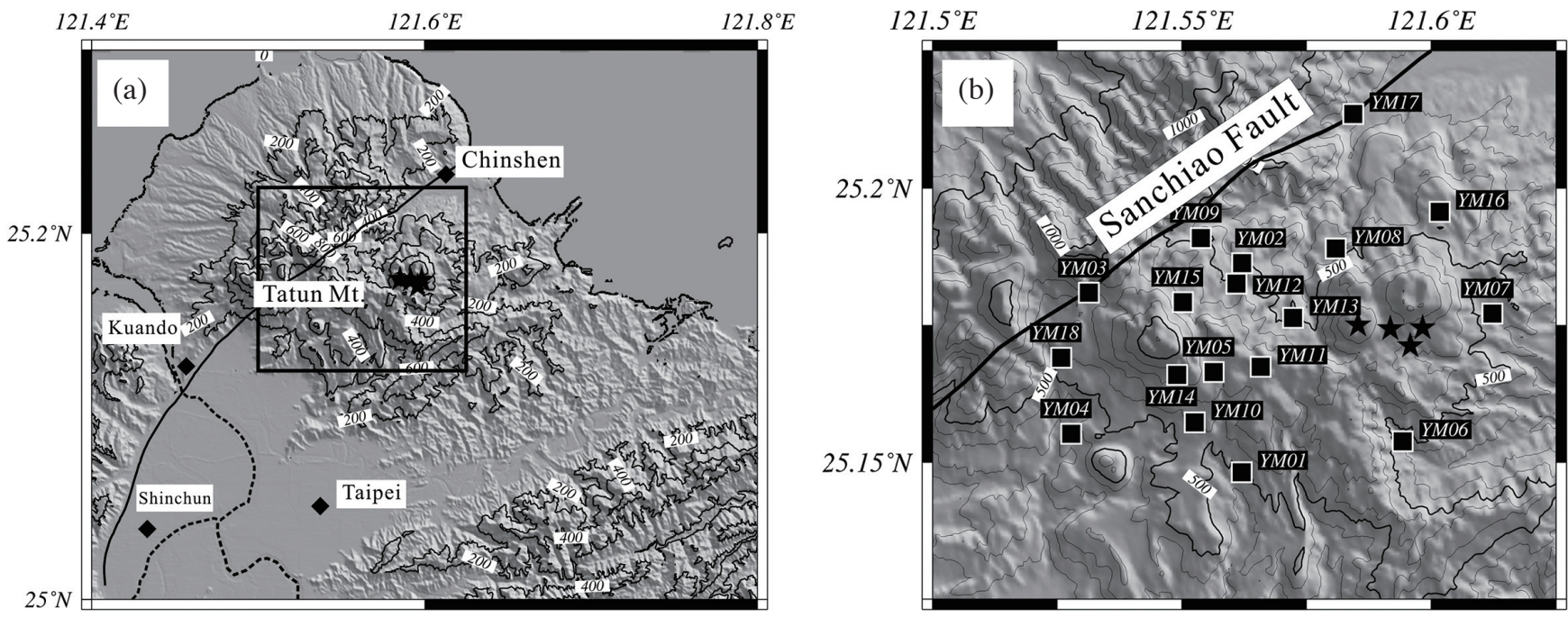

Fig. 1. (a) Locations of 4 felt earthquakes (stars) which occurred on October 20, 2009; and (b) a dense seismic network (squares) and 4 felt earthquakes (stars). The Shanchiao fault is shown by a solid line in both figures. The dotted line is the Tansui river. 

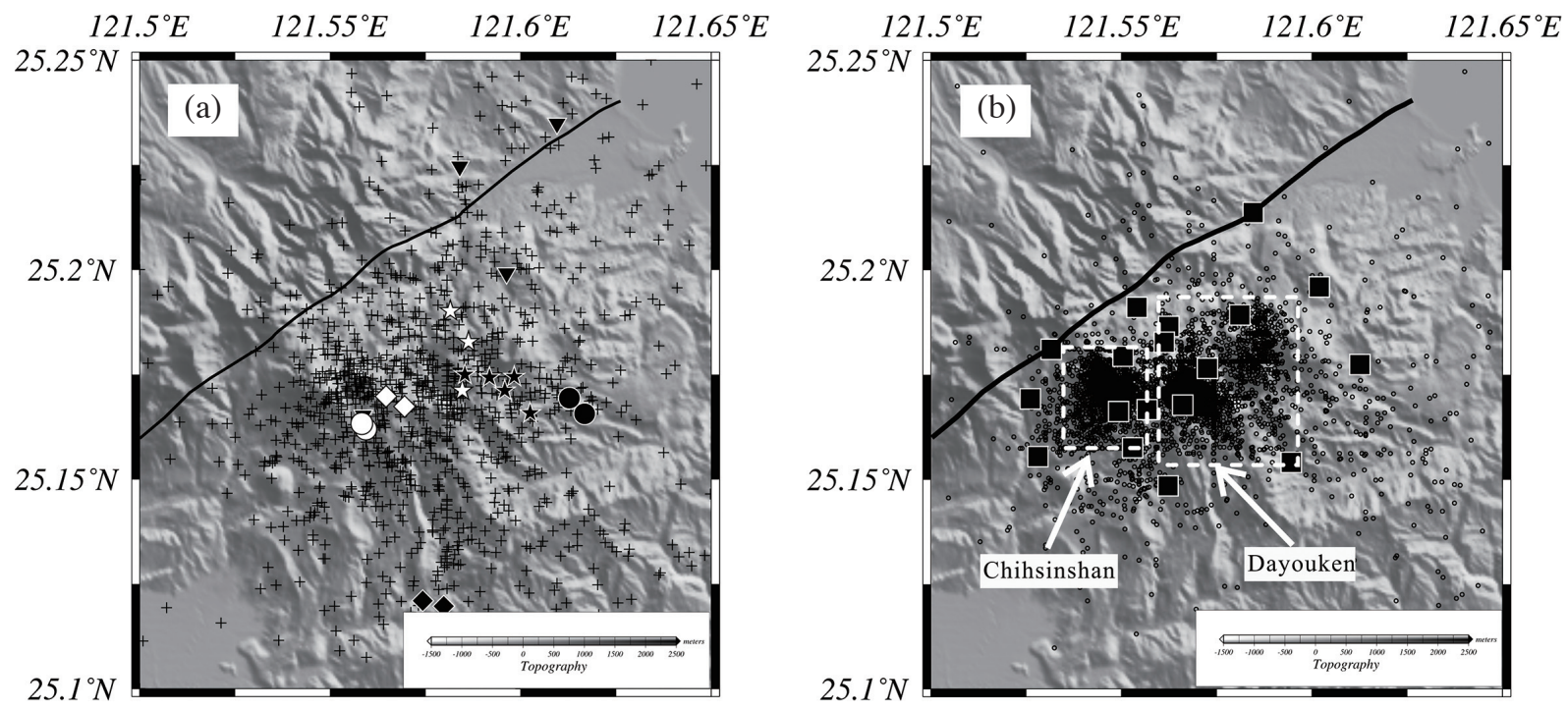

Fig. 2. Seismic activity in the Tatun volcanic area. (a) Background seismicity (pluses) and some significant seismic swarms (triangles, diamonds, circles and stars) reported by the CWBSN since 1973 and shown at Table 1. (b) Micro-earthquakes detected by the dense seismic stations (squares) between 2008 - 2010. The dashed boxes mark Dayouken and Chihhinshan areas with clustered earthquakes. The solid line in shows the fault trace of the Shanchiao Fault in both figures.

(e.g., Hudnut et al. 1989).

During the period between 1973 and 2007 at least 7 seismic sequences with magnitudes greater than 2.5 occurred in the shallow crust (Table 1). Prior to this October 20, 2009 earthquake sequence, 6 other seismic sequences took place with larger earthquakes whose magnitudes were comparable to each other. The 6 seismic sequences that occurred before 2009 were very similar to the typical seismic swarms that occur in volcanic or geothermal areas around the world. However, it is very difficult to investigate in detail further characteristics for the 7 seismic sequences because there were only very limited seismic stations in the Tatun volcanic area before 2003. Smaller earthquakes and detailed seismic features were largely unobserved by the regional seismic network [such as the Central Weather Bureau Seismic Network (CWBSN), and Taiwan Telemetered Seismic Network (TTSN) before 2003].

To improve seismic monitoring in the Tatun volcanic area, a dense seismic array (Lin et al. 2005a) was deployed in 2003. As of 2013 this seismic array is composed of 18 seismic stations within a small area of about $100 \mathrm{~km}^{2}$. Each of the seismic stations is equipped with a three-component broadband seismometer (Guralp CMG-6TD). The seismic data are recorded at 100 samples per second. Thus, seismic signals at frequencies of several tens of $\mathrm{Hz}$ to the $40 \mathrm{sec}$ period can be recorded at each seismic station.

In all, more than 3000 micro-earthquakes have been detected in the Tatun volcanic area since 2003. Most of them were clustered around two particular areas, Chihsinshan and Dayouken, at depths of around 2 - $5 \mathrm{~km}$ (Fig. 2b). Most of those micro-earthquakes were tectonic earthquakes which have a double-couple source and thus both P- and S-waves can be clearly identified (Lin et al. 2005a). A few of the micro-earthquakes belonged to typical volcanic earthquakes whose recorded waveforms look like Tornillos, monochromatic frequency or even long period (Lin et al. 2005a, b; Konstantinou et al. 2007). Each of those seismic observations suggests that volcanic activity in this area is still strong.

\section{PRELIMINARY SEISMICITY}

The seismic swarm that occurred on October 20, 2009 was well recorded by the dense seismic network with 18 stations in the Tatun volcanic area. In addition to the 4 felt earthquakes, 202 micro-earthquakes were detected between October 18 and 22. Based on the 1-D model (Lin and Yeh 1989) we located all of the earthquakes using the HYPO71 computer program (Lee and Lahr 1975). The local magnitudes $\left(\mathrm{M}_{\mathrm{L}}\right)$ of those earthquakes ranged from $1.9-3.2$ (Fig. 3). This earthquake sequence might be a typical seismic swarm because some of the small earthquakes occurred before the 4 felt earthquakes $\left(\mathrm{M}_{\mathrm{L}}\right.$ from 2.9 - 3.2). It is clear that 10 earthquakes occurred on October 19 and 22 earthquakes occurred just before the 4 felt earthquakes on October 20. In addition, the difference in the earthquake magnitudes between the felt earthquakes and other smaller earthquakes were not significant.

Most of the earthquakes were clustered in the Dayouken area with their focal depths less than $10 \mathrm{~km}$ (Fig. 4). All of the 4 felt earthquakes were located at depths around $3 \mathrm{~km}$. The depth profile striking along the NW-SE direction shows that most of the earthquakes were located at the hanging wall 
of the Shanchiao fault, if we assume that the fault plane dip angle is 62 degrees at the upper crust based on the fault trace at the surface (Lin et al. 2007). Although there were a few earthquakes located roughly along the expected fault plane, most of the earthquakes were located around several kilometers SE to the fault plane in the horizontal distance. For example, the 4 felt earthquakes were located about 2 or $3 \mathrm{~km}$ away from the fault plane in the horizontal direction. Moreover,

Table 1. Shallow seismic swarms (depth $<10 \mathrm{~km})$ in the Tatun volcanic area $\left(121.5^{\circ}-121.65^{\circ} \mathrm{E}, 25.1^{\circ}-25.25^{\circ} \mathrm{N}\right)$ since $1973(\mathrm{CWB})$.

\begin{tabular}{|c|c|c|c|c|c|c|}
\hline Date & Time (UTC) & Latitude & Longitude & Depth & $\mathbf{M}_{\mathbf{L}}$ & No. (symbol) of Swarm \\
\hline $1975 / 08 / 18$ & $22: 35$ & 121.5963 & 25.19917 & 6.20 & 2.86 & $1(\boldsymbol{\nabla})$ \\
\hline 1975/08/19 & $15: 59$ & 121.5587 & 25.16517 & 2.63 & 3.35 & $1(\boldsymbol{\nabla})$ \\
\hline $1975 / 08 / 19$ & $16: 40$ & 121.6095 & 25.23483 & 0.81 & 3.00 & $1(\boldsymbol{\nabla})$ \\
\hline 1975/08/19 & $17: 06$ & 121.584 & 25.22467 & 0.06 & 2.84 & $1(\boldsymbol{\nabla})$ \\
\hline 1988/06/11 & $00: 31$ & 121.5695 & 25.16733 & 3.66 & 3.14 & $2(\Delta)$ \\
\hline 1988/06/11 & $00: 43$ & 121.5647 & 25.16983 & 1.62 & 3.14 & $2(\Delta)$ \\
\hline 1988/07/03 & $05: 20$ & 121.568 & 25.15767 & 5.31 & 5.06 & $3(\boldsymbol{\Delta})$ \\
\hline 1988/07/03 & 06:03 & 121.5625 & 25.189 & 5.15 & 3.31 & $3(\boldsymbol{\Delta})$ \\
\hline 1994/01/18 & $05: 36$ & 121.5712 & 25.16017 & 9.25 & 2.71 & $4(\diamond)$ \\
\hline 1994/01/18 & $21: 42$ & 121.5128 & 25.20767 & 5.32 & 2.83 & $4(\diamond)$ \\
\hline $1997 / 06 / 24$ & $16: 37$ & 121.5798 & 25.11967 & 8.55 & 3.70 & $5(\diamond)$ \\
\hline $1997 / 06 / 25$ & $15: 30$ & 121.5743 & 25.121 & 8.59 & 2.75 & $5(\bullet)$ \\
\hline $1999 / 01 / 13$ & $12: 53$ & 121.5593 & 25.162 & 1.31 & 2.60 & $6(0)$ \\
\hline $1999 / 01 / 13$ & 13:03 & 121.5583 & 25.16333 & 7.73 & 2.56 & $6(0)$ \\
\hline $2004 / 02 / 24$ & $00: 24$ & 121.6128 & 25.16933 & 8.28 & 2.66 & $7(\bullet)$ \\
\hline $2004 / 02 / 24$ & $11: 22$ & 121.6168 & 25.16567 & 6.75 & 2.90 & $7(\bullet)$ \\
\hline $2007 / 04 / 25$ & $05: 47$ & 121.5863 & 25.18283 & 7.20 & 3.13 (felt) & $8(\hbar)$ \\
\hline $2007 / 04 / 25$ & $05: 52$ & 121.5815 & 25.19017 & 9.29 & 2.50 & $8(\lesssim)$ \\
\hline $2007 / 04 / 25$ & $12: 25$ & 121.5847 & 25.17117 & 3.53 & 2.75 & $8(\hbar)$ \\
\hline $2009 / 10 / 20$ & $05: 40$ & 121.5958 & 25.17117 & 6.67 & 3.19 (felt) & $9(\star)$ \\
\hline $2009 / 10 / 20$ & $05: 54$ & 121.5983 & 25.1745 & 7.14 & 2.84 (felt) & $9(\star)$ \\
\hline $2009 / 10 / 20$ & $05: 55$ & 121.5918 & 25.17433 & 7.45 & 3.10 (felt) & $9(\star)$ \\
\hline $2009 / 10 / 20$ & 06:03 & 121.6025 & 25.16583 & 7.04 & 2.74 & $9(\star)$ \\
\hline $2009 / 10 / 20$ & $06: 32$ & 121.5853 & 25.175 & 6.65 & 3.02 (felt) & $9(\star)$ \\
\hline
\end{tabular}

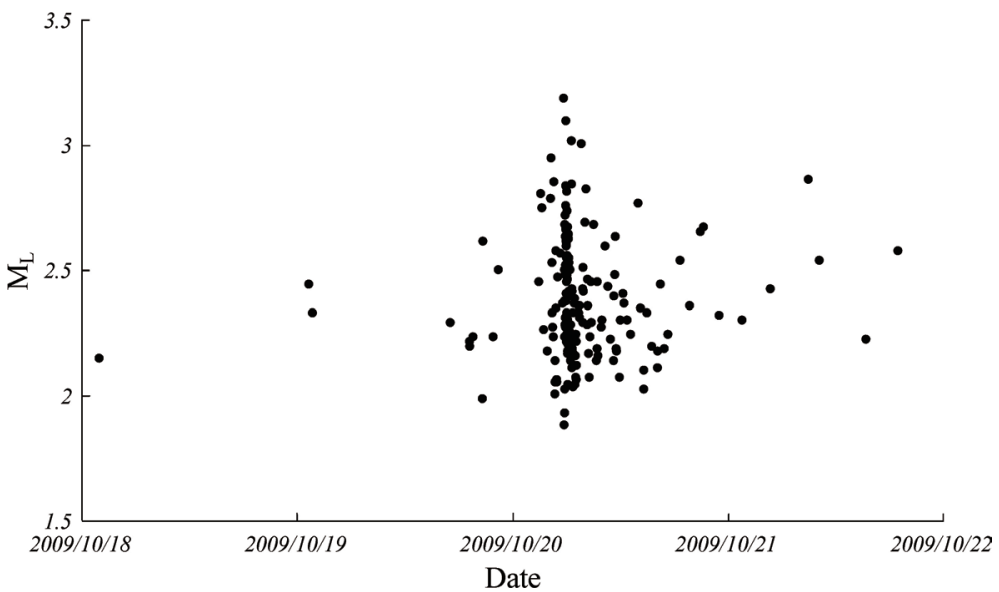

Fig. 3. Plot of seismic magnitude $\left(\mathrm{M}_{\mathrm{L}}\right)$ of the earthquake sequence with time of occurrences from October 18 - 22, 2009. 

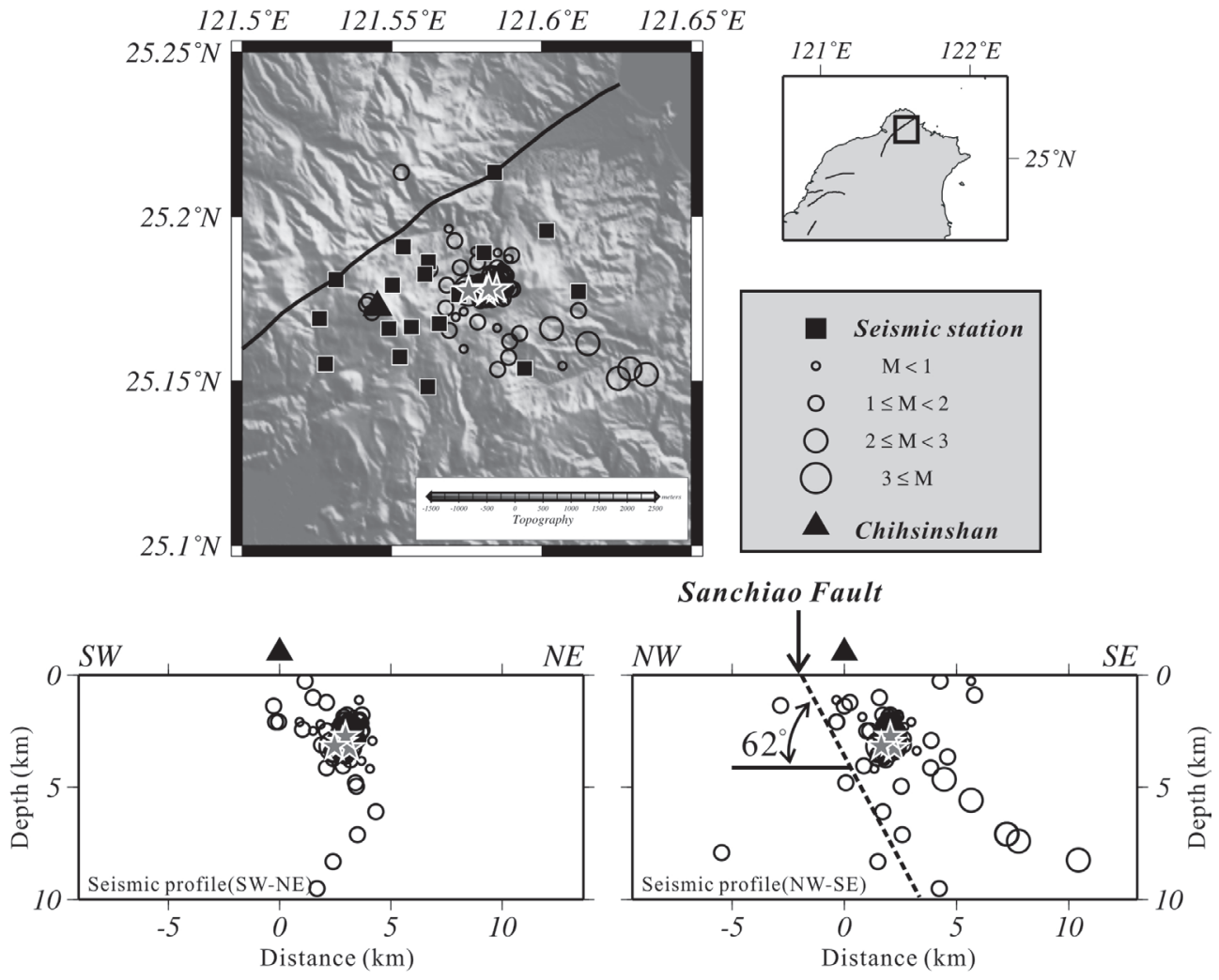

Fig. 4. The preliminary seismicity of the felt earthquakes (stars) and micro-earthquakes (crosses) located by HYPO71. The surface trace of the Shanchiao fault and locations of both seismic stations and Chihsinshan are shown in the map by the solid line, squares and triangle (upper right panel), respectively. The seismic projections along both the NW-SE and NE-SW directions are shown in the lower panels. The dotted line in the NW-SE profile marks the expected fault plane based on the projection of the fault trace on the surface.

the depth profile striking along the NE-SW direction shows the seismicity was only clustered at a narrow section within a few kilometers in width, not a plane. This roughly indicates that the seismicity of most earthquakes may not follow the expected fault plane.

\section{RELOCATED SEISMICITY}

We employed the double difference method to improve earthquake location accuracy (Waldhauser and Ellsworth 2000) to relocate 188 earthquakes that occurred over the October 18 - 22, 2009 period. This relocation method has been successfully applied at other areas for accurate earthquake location (e.g., Fukuyama et al. 2003; Schaff and Waldhauser 2005). We selected an appropriate velocity model (Table 2 ), which is the same as that used in locating earthquakes using the HYPO71 (Lee and Lahr 1975). In all, 202 neighbor earthquakes were sorted using this method to relocate their hypocenters. There were 16183 sets of differential times recorded between seismic stations. Because most Pand S-waves are impulsive (i.e., Fig 5), the arrival times of those earthquakes at each station were clearly read from the seismograms without further applying the cross-correlation technique. One hundred eighty-eight earthquakes were suc- cessfully relocated. The total RMS (root-mean-square) difference between the observed and theoretical arrival times was reduced from $0.12-0.02 \mathrm{sec}$ and the earthquake location accuracy was significantly better than that from the preliminary earthquake locations. The estimated uncertainty is less than a few hundred meters.

The relocation results (Fig. 6) show the seismicity was significantly different from the preliminary seismicity using HYPO71 (Fig. 4). The relocated seismicity using the double-difference method was more clustered than that from the preliminary seismicity. This result is quite reasonable because the earthquake accuracy relocated using the double-difference method can significantly improve the location among a group of earthquakes. Second, it is interesting to see that the relocated seismicity was clearly clustered within a pipe-like zone and dipping toward the SE direction. Although a similar pattern can be seen from the preliminary seismicity, the relocated seismicity shows significant clustering seismicity for later interpretation. Third, it is difficult to see that any earthquake was located around the expected fault plane. This is dramatically different from the preliminary seismicity located by HYPO71, which shows a few earthquakes clustered around the expected fault plane (Fig. 4). Fourth, most of the earthquakes were clustered in 
the seismic zone, which dips toward the SE and is roughly parallel to the expected fault plane with a horizontal offset of about $2-3 \mathrm{~km}$. Compared to the preliminary locations the relocated earthquakes were not only more clustered and the offset between the seismicity and the expected fault plane was also clearer. In short, the seismic swarm that occurred in the period between October 18 and 22 might not be associated with the Shanchiao fault, but volcanic activity at the Dayouken area.

\section{FOCAL MECHANISM}

Because most earthquakes are located within a seismic network, seismic station coverage is well-suited for determining the focal mechanism by polarizing the first P-waves. We further selected earthquakes based on the following two criteria to obtain reliable focal mechanisms. The selected earthquakes were located within the seismic array as well as having focal depths that were less than $10 \mathrm{~km}$. The focal depth of each selected earthquake was determined using recording from more than 7 stations. In all, 72 focal mechanisms were determined among 188 earthquakes occurring from October 18 - 22 (Appendix A).

The results show that most of these earthquakes had normal-faulting mechanisms (Fig. 7). Fifty earthquakes had normal faulting among the 72 focal mechanisms. Most of the larger earthquakes exhibited normal faulting mechanism. In particular, the 4 felt earthquakes clearly belonged to a typical normal-faulting mechanism. In addition to normalfaulting mechanisms, thrust-faulting and strike-slip-faulting mechanisms were also determined in the seismic swarms that occurred in October 2009. The numbers for thrustfaulting and strike-slip-faulting are 18 and 4, respectively. Sixty-nine percent of these events revealed normal faulting mechanism, indicating that the maximum stress was close to the vertical direction.

Table 2. One-dimensional velocity model for the Tatun Mt. area (Lin and Yeh 1989).

\begin{tabular}{ccc}
\hline Depth $(\mathbf{k m})$ & Velocity model of P-wave $\left(\mathbf{k m ~ s e c} \mathbf{~ s}^{-1}\right)$ & Velocity model of S-wave $\left(\mathbf{k m ~ s e c}^{-1}\right)$ \\
\hline Above surface - 1.0 & 3.79 & 2.13 \\
$1.0-2.0$ & 4.07 & 2.29 \\
$2.0-3.0$ & 4.55 & 2.56 \\
$3.0-5.0$ & 5.12 & 2.88 \\
$5.0-7.0$ & 5.39 & 3.03 \\
$7.0-9.0$ & 5.98 & 3.36 \\
$9.0-17.0$ & 6.10 & 3.43 \\
$17.0-36.0$ & 6.70 & 3.76 \\
Under 36.0 & 7.80 & 4.38 \\
\hline
\end{tabular}

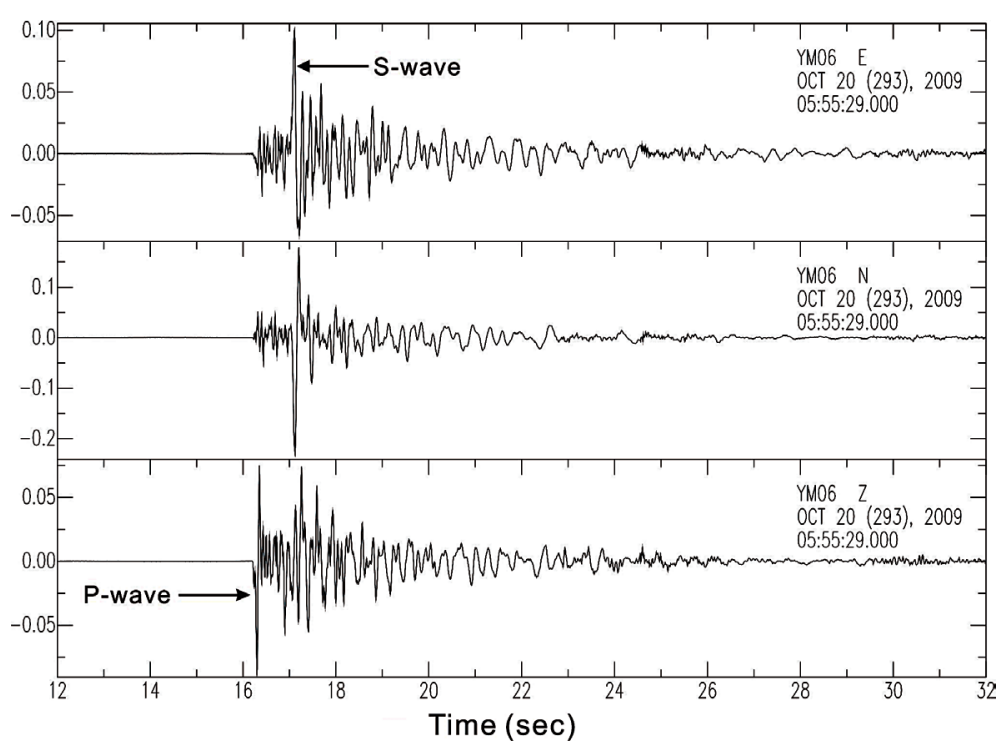

Fig. 5. An example of 3-component seismograms showing impulsive P- and S-waves. 


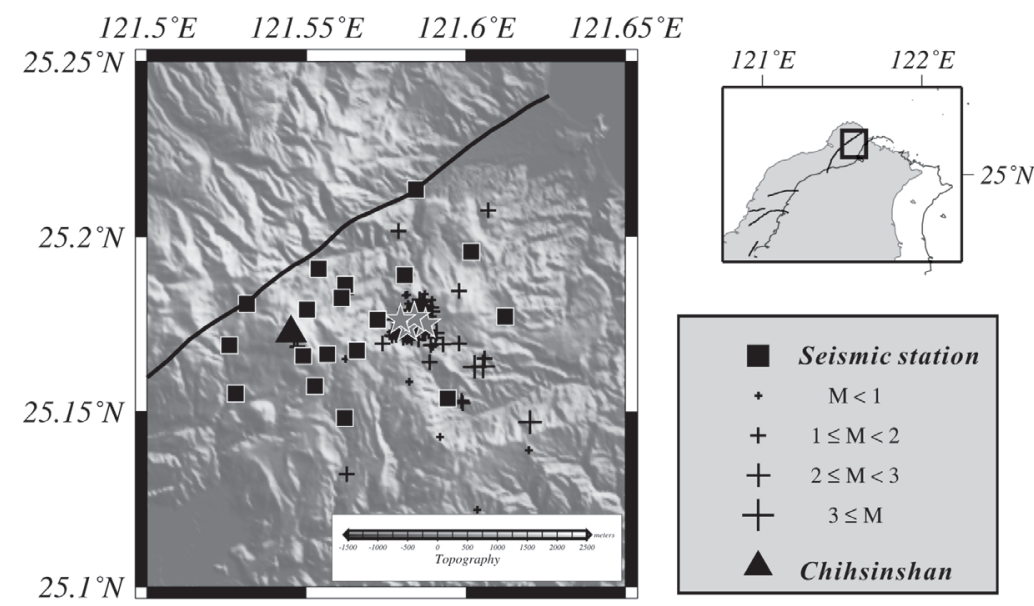

Sanchiao Fault
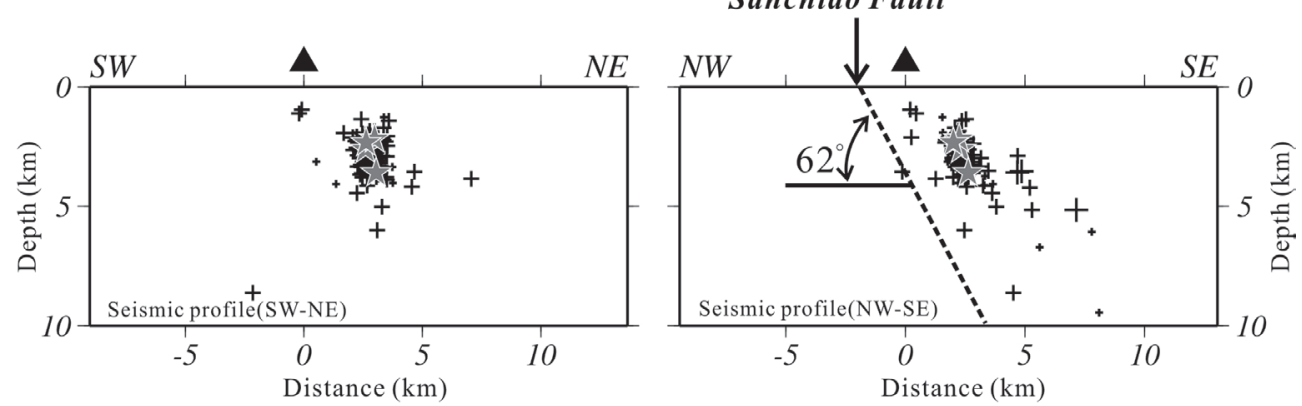

Fig. 6. The seismicity of the felt earthquakes (gray stars) and micro-earthquakes (crosses) relocated by the double-difference method. The other symbols are the same as those in Fig. 4.



Fig. 7. The focal mechanisms of the felt earthquakes (red stars) and their associated micro-earthquakes (crosses) in the Tatun volcanic area from October 18 - 22, 2009. The red, green, and blue beach balls indicate the reverse, strike-slip, and normal mechanisms, respectively. The red solid line shows the trace of the Shanchiao Fault. 


\section{SEISMIC $b$-VALUE}

In order to distinguish whether this seismic swarm is associated with volcanic activity or active fault, we examined the seismic $b$-value of 188 earthquakes from October $18-22$ in 2009. It is well known in seismological science that the seismic $b$-value is the slope of the frequency-magnitude relationship (Gutenberg and Richter 1944) for a given population of earthquakes:

$\log (\mathrm{N})=a-b \mathrm{M}$

where $\mathrm{N}$ is the cumulative number of earthquakes with magnitudes larger than $\mathrm{M}$, and $a$ and $b$ are constants. In most tectonic areas the $b$-value averages about 1.0 (Frohlich and Davis 1993). In contrast, volcanic areas are often characterized by $b$-values greater than 1.0 with values as high as 3.0 (McNutt 2005).

Figure 8 shows the plot of $\log (\mathrm{N})$ vs. magnitude. We selected only the earthquakes with magnitudes between 2.2 - 3.1 to calculate the seismic $b$-value from October 18 - 22 in 2009. A typical least-square regression was employed to calculate the $b$-value with a very reliable result. It clearly shows an extremely high $b$-value of 2.17 from this seismic swarm; significantly greater than those in the Taiwan area (Wang 1994). Thus, the observation of an extremely high $b$-value of 2.17 in this study strongly indicates that the seismic swarm was more like the seismic characteristics in volcanic or geothermal areas than in fault zones.

\section{RESULTS AND DISCUSSION}

It is interesting to know whether the normal faulting earthquakes in the Tatun volcanic area have magma movement origin or result from the Shanchiao fault. It is well known that normal faulting mechanisms are very often ob- tained in volcanic or geothermal areas. Thus, $69 \%$ of the normal faulting events in the 4 days observation in the Tatun area might directly reflect volcanic activity. However, those normal faulting earthquakes in the Tatun area might also be explained by the Shanchiao fault, which is an active normal fault according to the Central Geological Survey report (Lin et al. 2007). Therefore, it is difficult to justify that the seismic swarm that occurred in October 2009 was associated with either volcanic activity or the Shanchiao active fault based on focal mechanisms alone. In other words, some other observations must be considered to determine possible mechanism that generated those earthquakes from October 18 - 22, 2009.

Another important information from the earthquake spatial distribution in the Tatun volcanic area shows that the seismic swarm might not be associated with the Shanchiao fault, but Tatun volcanic activity. First of all, the earthquakes were only clustered within a more pipe-like seismic zone than a plane (Fig. 6). In fact, the pipe-like seismic zone has been observed at some typically active volcanoes, such as the Sakurajima volcano in Kyusu, Japan (e.g., Nishi 1978, 1980; Yokoyama 1986). Second, there was a distinguished offset between the seismic zone and the expected fault plane in the shallow crust (Fig. 6). The possibility that this seismic swarm is associated with other blind faults cannot be totally ruled out. The clustered earthquakes were located just beneath the Dayouken area, which is the strongest fumarole in the Tatun volcanic area. This strongly suggests that this seismic swarm is associated with volcanic activity.

The temporary earthquake sequence distribution indicates that they were more like the seismic swarms common to volcanic areas than micro-earthquakes in a fault zone. There was no significant difference in earthquake magnitudes from October 18 - 22, 2009 (Fig. 3). Some earthquakes occurred before and after the 4 felt earthquakes on October 20 (Fig. 4). Although a few of the seismic swarms might have also taken place in some faults with aseismic slips, this

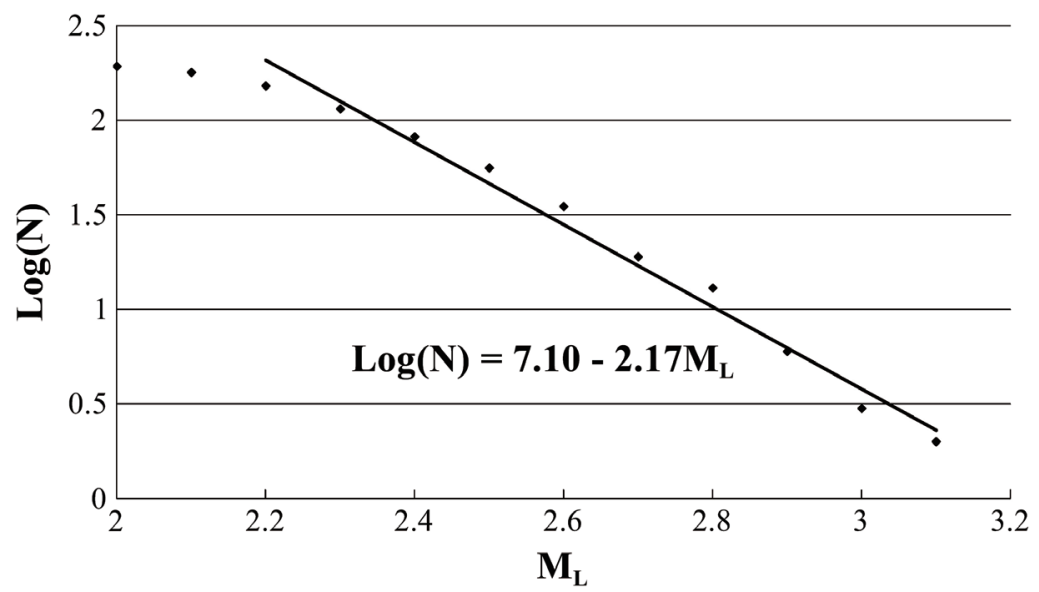

Fig. 8. Plot of $\log (N)$ vs. magnitude $\left(M_{L}\right)$ from the seismic swarm from October $18-22$ in 2009 , where $N$ is the number of earthquakes. 
is a seismic swarm that typically occurs in volcanic or geothermal areas (Kim et al. 2005; Lin et al. 2005a, b; Konstantinou et al. 2007). On the other hand, the micro-earthquakes in the fault zone are often triggered by the main-shock and the number of triggered aftershocks then decays significantly over time (Lin 2004). However, the seismic events detected on October 20 did not show any significant decay through time (Fig. 3). Thus, the earthquake temporal distribution observation is not consistent with the typical seismic characteristics in the fault zone.

An extremely high $b$-value of 2.17 from this seismic swarm strongly suggests that the seismic swarm was more like the seismic characteristics in volcanic or geothermal areas than in fault zones or general tectonic regions in the world. It is well-known that the $b$-value obtained in the fault zone or general tectonic area is around 1.0. High $b$-values have often been reported in many volcanic or geothermal areas. The earthquake sequence that occurred on October 20, 2009 might be associated more with possible volcanism than active fault in the Tatun volcanic area. This result is consistent with previous studies (Kim et al. 2005; Lin et al. 2005a, b; Konstantinou et al. 2007) that suggested most of the seismic activity in the Tatun volcanic area is probably associated with hydrothermal/magmatic activities.

\section{CONCLUSION}

A series of felt earthquakes occurred at the Tatun volcanic area off the northern tip of Taiwan on October 20, 2009. Careful examination of the seismic data recorded by a dense seismic array in the Tatun volcanic area shows that those earthquakes were clustered in the shallow crust beneath the Dayoukeng area, where the strongest fumarole in the Tatun volcanic area is located. Determination of 72 focal mechanisms among those earthquakes shows that most of the focal mechanisms belong to normal faulting, which can result from either Tatun volcanic activity or the Shanchiao fault. Based on further seismic variations in both temporary and spatial distributions as well as an extremely high $b$-value of 2.17 , we strongly suggest that the earthquake sequence that occurred on October 20, 2009 was a typical seismic swarm associated with volcanism in the Tatun volcanic area. Therefore, potential seismic threats associated with volcanic activity in the Tatun area cannot be totally excluded in the future.

Acknowledgements The authors would like to thank the National Science Council, Academia Sinica, Central Weather Bureau, Central Geological Survey and Taiwan Power Company for their financial support. Seismic data provided by the Central Weather Bureau and Institute of Earth Sciences, Academia Sinica is appreciated. We thank the two Anonymous Reviewers for their valuable comments and suggestions for improving this paper.

\section{REFERENCES}

Belousov, A., M. Belousova, C. H. Chen, and G. F. Zellmer, 2010: Deposits, character and timing of recent eruptions and gravitational collapses in Tatun Volcanic Group, Northern Taiwan: Hazard-related issues. J. Volcanol. Geotherm. Res., 191, 205-221, doi: 10.1016/j. jvolgeores.2010.02.001. [Link]

Chen, C. H. and S. B. Lin, 2002: Eruptions younger than 20Ka of the Tatun Volcano Group as viewed from the sediments of the Sungshan Formation in Taipei basin. West. Pac. Earth Sci., 2, 191-204.

Chen, C. H. and Y. J. Wu, 1971: Volcanic geology of the Tatun geothermal area, northern Taiwan. Proc. Geol. Soc. China, 14, 5-20.

Frohlich, C. and S. D. Davis, 1993: Teleseismic $b$ values; or, much ado about 1.0.J. Geophys. Res., 98, 631-644, doi: 10.1029/92JB01891. [Link]

Fukuyama, E., W.L. Ellsworth, F. Waldhauser, and A. Kubo, 2003: Detailed fault structure of the 2000 western Tottori, Japan, earthquake sequence. Bull. Seismol. Soc. Am., 93, 1468-1478, doi: 10.1785/0120020123. [Link]

Gutenberg, B. and C. F. Richter, 1944: Frequency of earthquakes in California. Bull. Seismol. Soc. Am., 34, 185188.

Hill,D.P., 1977: A model for earthquake swarms.J.Geophys. Res., 82, 1347-1352, doi: 10.1029/JB082i008p01347. [Link]

Ho, C. S., 1988: An Introduction to the Geology of Taiwan Explanatory Text of the Geologic Map of Taiwan, $2^{\text {nd }}$ edition, Ministry of Economic Affairs, Central Geological Survey, Taiwan, Taipei, 192 pp.

Huang, S. Y., C. M. Rubin, Y. G. Chen, and H. C. Liu, 2007: Prehistoric earthquakes along the Shanchiao fault, Taipei Basin, northern Taiwan. J. Asian Earth Sci., 31, 265-276, doi: 10.1016/j.jseaes.2006.07.025. [Link]

Hudnut, K. W., L. Seeber, and J. Pacheco, 1989: Cross-fault triggering in the November 1987 Superstition Hills earthquake sequence, southern California.Geophys.Res. Lett., 16, 199-202, doi: 10.1029/GL016i002p00199. [Link]

Kim, K. H., C. H. Chang, K. F. Ma, J. M. Chiu, and K. C. Chen, 2005: Modern seismic observations in the Tatun volcano region of northern Taiwan: seismic/volcanic hazard adjacent to the Taipei metropolitan area. Terr. Atmos. Ocean. Sci., 16, 579-594.

Konstantinou, K. I., C. H. Lin, and W. T. Liang, 2007: Seismicity characteristics of a potentially active Quaternary volcano: The Tatun Volcano Group, northern Taiwan. J. Volcanol. Geotherm. Res., 160, 300-318, doi: 10.1016/j.jvolgeores.2006.09.009. [Link]

Lee, W. H. K. and J. C. Lahr, 1975: HYPO71 (revised): A computer program for determining hypocenter, magnitude, and first motion pattern of local earthquakes. 
U. S. Geological Survey, Open-File Report, 75-311, United States Department Of The Interior, Geological Survey, National Center for Earthquake Research, $100 \mathrm{pp}$.

Lin, C. H., 2002: Active continental subduction and crustal exhumation: The Taiwan orogeny. Terr. Nova, 14, 281287, doi: 10.1046/j.1365-3121.2002.00421.x. [Link]

Lin, C. H., 2004: Repeated foreshock sequences in the thrust faulting environment of eastern Taiwan. Geophys. Res. Lett., 31, L13601, doi: 10.1029/2004GL019833. [Link]

Lin, C. H. and Y. H. Yeh, 1989: Three-dimensional velocity structures in the Datun-Shan area. (unpublished).

Lin, C. H., K. I. Konstantinou, H. C. Pu, C. C. Hsu, Y. M. Lin, S. H. You, and Y. P. Huang, 2005a: Preliminary results from seismic monitoring at the Tatun volcanic area of northern Taiwan. Terr. Atmos. Ocean. Sci., 16, 563-577.

Lin, C. H., K. I. Konstantinou, W. T. Liang, H. C. Pu, Y. M. Lin, S. H. You, and Y. P. Huang, 2005b: Preliminary analysis of volcanoseismic signals recorded at the Tatun Volcano Group, northern Taiwan. Geophys. Res. Lett., 32, L10313, doi: 10.1029/2005GL022861. [Link]

Lin, C. W., S. T. Lu, T. S. Shih, Z. Y. Chen, and Y. H. Lin, 2007: Active faults of northern Taiwan, Ministry of Economic Affairs, Central Geological Survey, Special Publication, Vol. 19, Taiwan, Taipei, 127 pp.

McNutt, S. R., 2005: Volcanic seismology. Annu. Rev. Earth Planet. Sci., 32, 461-491, doi: 10.1146/annurev. earth.33.092203.122459. [Link]

Murase, M., C. H., Lin, F. Kimata, H. Mori, and H. C. Pu, 2014: The volcano-hydrothermal activity detected by precise leveling surveys at Tatun volcano group, North Taiwan. (in preparing)

Nishi, K., 1978: On the focal mechanism of volcanic earthquakes in Sakurajima volcano. Ann. Rep. Dis. Prey. Res. Inst., Kyoto Univ., 21, 145-152. (in Japanese)

Nishi, K., 1980: Spectral study on the volcanic earthquake (I). Ann. Rep. Dis. Prey. Res. Inst., Kyoto Univ., 23B-1, 29-35. (in Japanese)

Schaff, D. P. and F. Waldhauser, 2005: Waveform cross-correlation-based differential travel-time measurements at the northern California seismic network. Bull. Seismol. Soc. Am., 95, 2446-2461, doi: 10.1785/0120040221. [Link]

Song, S. R., T. F. Yang, S. H. Yeh, S. J. Tsao, and H. J. Lo, 2000: The Tatun Volcano Group is active or extinct? Proc. Geol. Soc. China, 43, 521-534.

Waldhauser, F. and W. L. Ellsworth, 2000: A doubledifference earthquake location algorithm: Method and application to the northern Hayward Fault, California. Bull. Seismol. Soc. Am., 90, 1353-1368, doi: 10.1785/0120000006. [Link]

Wang, J. H., 1994: On the correlation of observed Gutenberg-Richter's $b$ value and Omori's $p$ value for after- shocks. Bull. Seismol. Soc. Am., 84, 2008-2011.

Wang, W. H. and C. H. Chen, 1990: The volcanology and fission track age dating of pyroclastic deposits in Tatun Volcano Group, northern Taiwan. Acta Geol. Taiwan., 28, 1-30.

Yang, T. F., Y. Sano, and S. R. Song, 1999: ${ }^{3} \mathrm{He} /{ }^{4} \mathrm{He}$ ratios of fumaroles and bubbling gases of hot springs in Tatun Volcano Group, North Taiwan. Il Nuovo Cimento Soc. Ital. Fisica C, 22, 281-286.

Yang, T. F., H. H. Ho, P. S. Hsieh, N. J. Lin, Y. G. Chen, and C. H. Chen, 2003: Compositions and sources of fumarolic gases from Tatun Volcano Group, north Taiwan. J. Natl. Park, 13, 127-156.

Yokoyama, I., 1986: Crustal deformation caused by the 1914 eruption of Sakurajima volcano, Japan and its secular changes. J. Volcanol. Geotherm. Res., 30, 283 304, doi: 10.1016/0377-0273(86)90058-2. [Link]

\section{APPENDIX A}
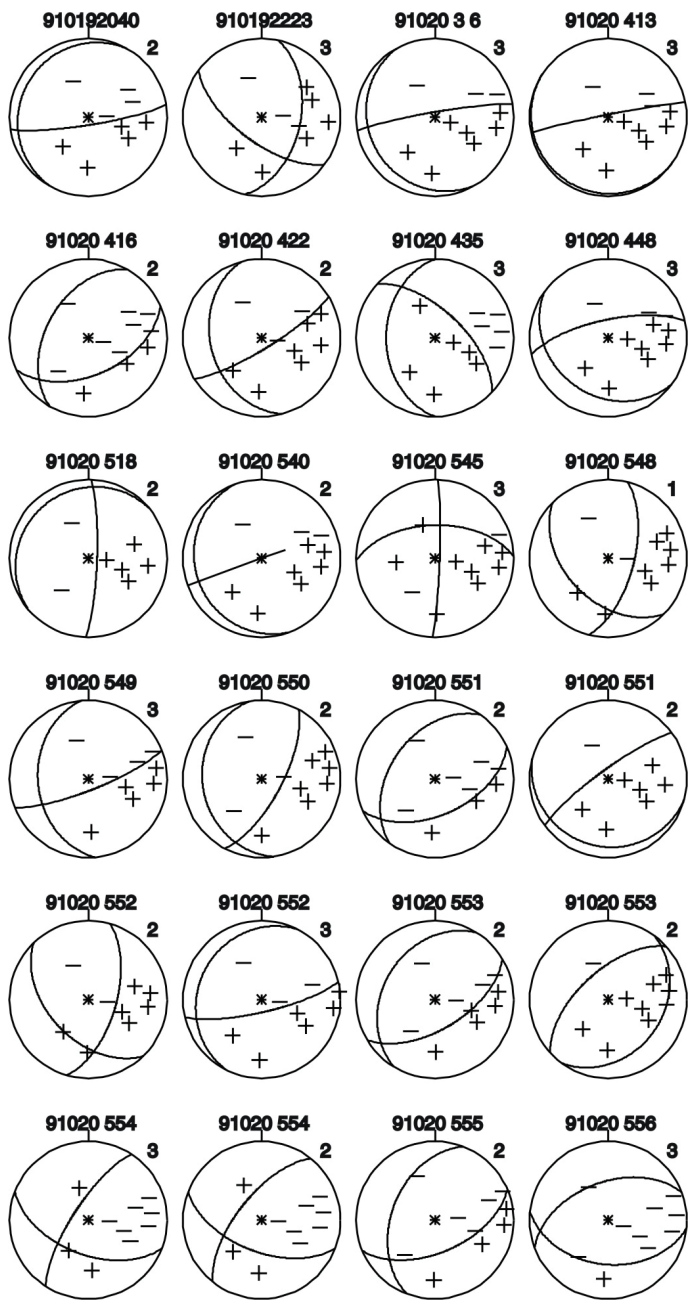

Fig. A1. Fault plane solutions determined from the P-wave polarities recorded in the Tatun volcanic area over October 18 - 22, 2009. The first motions of both up (+) and down (-) are plotted in each fault plane solution. The numbers on the top and upper-right corner of each fault plane solution show the occurrence time and the focal depth, respectively. 

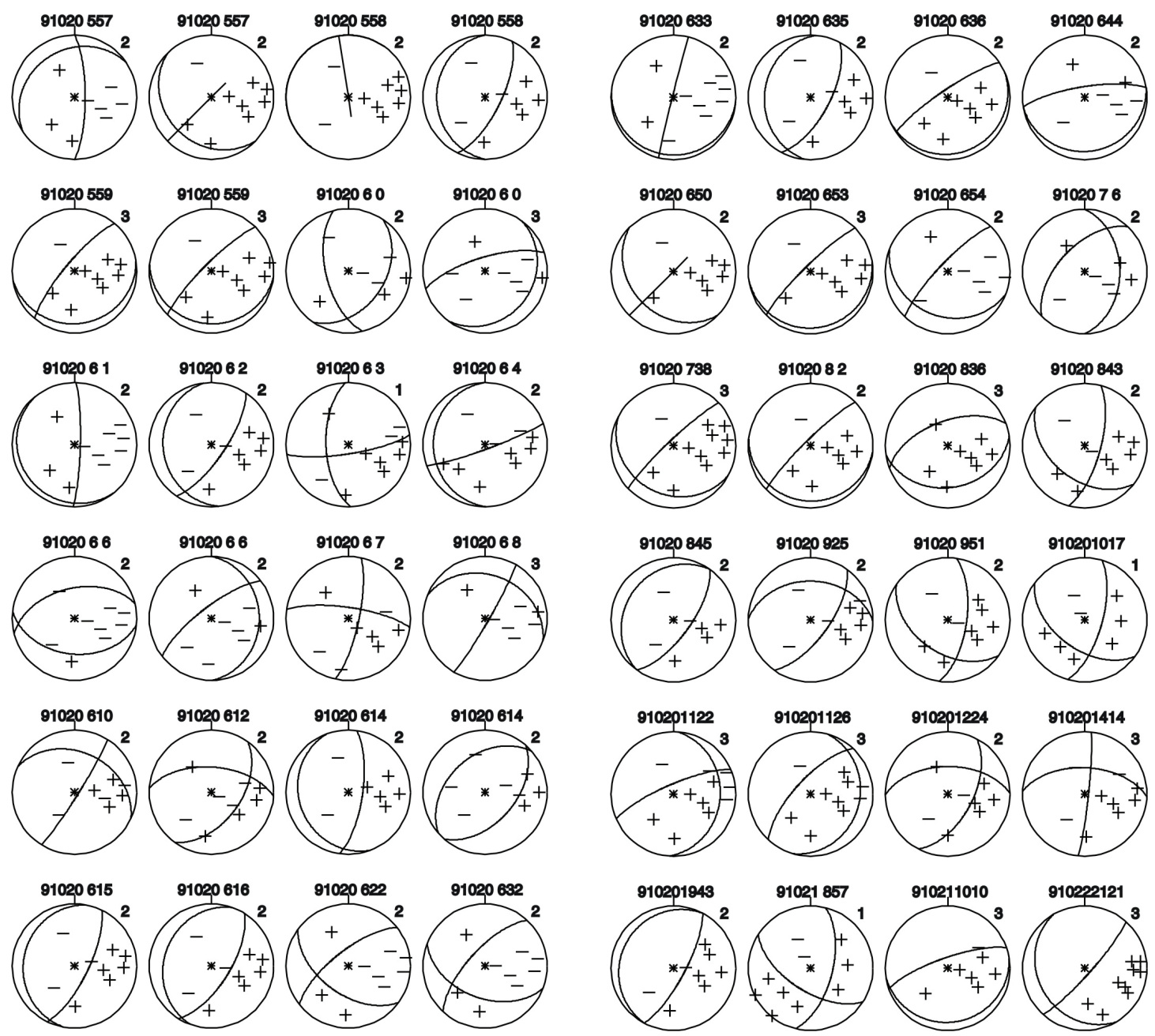

Fig. A1. (Continued) 